\title{
PEMBUATAN EDIBLE FILM DARI PATI BUAH LINDUR DENGAN PENAMBAHAN GLISEROL DAN KARAGINAN
}

\section{Edible Film from Lindur Fruit Starch with Addition of Glycerol and Carrageenan}

\author{
Agoes M Jacoeb*, Roni Nugraha, Siluh Putu Sri Dia Utari \\ Departemen Teknologi Hasil Perairan, Fakultas Perikanan dan Ilmu Kelautan, \\ Institut Pertanian Bogor, Kampus IPB Darmaga, Jalan Agatis, Bogor 16680 Jawa Barat \\ Telepon (0251) 8622909-8622906, Faks. (0251) 8622907 \\ *Korespondensi: agoes59@yahoo.de
}

Diterima 20 September 2013/Disetujui 01 April 2014

\begin{abstract}
Abstrak
Buah lindur (Bruguiera gymnorrhiza) mengandung karbohidrat yang tinggi dan belum dimanfaatkan secara optimal. Penelitian ini bertujuan untuk menentukan formulasi edible film dari buah lindur dan mengkarakterisasi produk yang dihasilkannya. Edible film dibuat dengan menambahkan tepung pati buah lindur sebesar 4\%; perlakuan gliserol $1 \%$ dan 1,5\%; dan konsentrasi karaginan 2\%, 2,5\% dan $3 \%$. Nilai ketebalan edible film yang dihasilkan dari keenam formula berkisar 0,13-0,20 mm sedangkan nilai kuat tarik berkisar 132,88-168,33 kgf/ $\mathrm{cm}^{2}$. Nilai persen pemanjangan berkisar 177,7-181,21\% dan nilai laju transmisi uap air berkisar 231,23-298,82 g/m²/24 jam. Pati buah lindur sangat potensial untuk dijadikan edible film.
\end{abstract}

Kata kunci: Bruguiera gymnorrhiza, edible film, kuat tarik, pati, persen pemanjangan

\section{Abstract}

Bruguiera gymnorrhiza fruit was found to have high starch content, yet it has not been optimally utilized. Therefore this research was aimed to utilized the starch from B. gymnorrhiza fruit as edible film material and characterized the produced edible film. The edible film were made from $4 \%$ of starch, mixed with glycerol (1\% and 5\%) and carrageenan (2,2.5, and 3\%). The thickness of edible film were in range of $0.13-0.20 \mathrm{~mm}$ with tensile strength of $132.88-168.33 \mathrm{kgf} / \mathrm{cm}^{2}$. Elongation percentage and water vapor transmission rate were $177.7-181.21 \%$ and $231.23-298.82 \mathrm{~g} / \mathrm{m}^{2} / 24 \mathrm{~h}$, respectively. Thus, starch from $B$. gymnorrhiza fruit has a potential to be utilized as edible film material.

Keywords: Bruguiera gymnorrhiza, edible film, elongation, starch, tensile strength

\section{PENDAHULUAN}

Perkembangan era globalisasi dan semakin bertambahnya jumlah penduduk di dunia menyebabkan kebutuhan pangan meningkat. Masyarakat dunia semakin memahami akan pentingnya kualitas pangan, yaitu dengan meningkatnya kesadaran penggunaan kemasan yang mudah terdegradasi dan aman bagi kesehatan. Penggunaan kemasan sintetis yang umum digunakan selama ini menimbulkan masalah baru bagi kesehatan dan lingkungan hidup. Teknologi kemasan yang aman dan tidak merusak lingkungan sangat diperlukan, contohnya edible film (McHugh dan Krochta 1994).
Edible film adalah lapisan tipis yang terbuat dari bahan yang dapat dimakan, digunakan sebagai pelapis permukaan komponen makanan yang berfungsi untuk menghambat migrasi kelembaban, oksigen, karbondioksida, aroma, lipid (Krochta dan Johnston 1997). Tiga komponen penyusun dasar edible film yaitu hidrokoloid (protein, polisakarida, alginat), lipid (asam lemak, asil gliserol, wax atau lilin) dan komposit (campuran hidrokoloid dan lipid) (Fennema et al. 1994). Pati sering digunakan dalam industri pangan sebagai biodegradable film untuk menggantikan polimer plastik karena ekonomis, dapat diperbaharui, dan memberikan karakteristik fisik yang baik. 
Pati dapat digunakan sebagai bahan baku pembuatan edible film (Bourtoom 2008).

Kandungan karbohidrat buah lindur $(85,1 \mathrm{~g} / 100 \mathrm{~g})$, lebih tinggi dari kandungan karbohidrat dari beras $(78,9 \mathrm{~g} / 100 \mathrm{~g})$ dan jagung $(63,3 \mathrm{~g} / 100 \mathrm{~g})$ (Fortuna 2005). Penelitian mengenai edible film telah banyak dilakukan di Indonesia misalnya karakteristik edible film dari pati sagu dengan penambahan gliserol dan karaginan (Anggraini 2012); edibel film dari karaginan (Handito 2011); dan edible film dari pati jagung (Kusumawati dan Putri 2013).

Ketersediaan informasi dan literatur mengenai karakteristik buah lindur sebagai edible film dari buah lindur di Indonesia masih sedikit sehingga penelitian ini sangat penting untuk dilakukan. Penelitian ini bertujuan untuk menentukan karakteristik edible film yang dihasilkan dari pati buah lindur.

\section{BAHAN DAN METODE}

\section{Bahan dan Alat}

Bahan yang digunakan dalam penelitian iniadalah buah lindur (Bruguieragymnorrhiza) yang diperoleh dari Pulau Kay, Kota Tual, Kabupaten Maluku Tenggara, natrium bisulfit $\left(\mathrm{Na}_{2} \mathrm{~S}_{2} \mathrm{O}_{3}\right)$, tepung pati buah lindur, gliserol, kappa-karagenan komersil, akuades, silika gel dan vaselin, parafin, xylol, toluidine blue, etanol, larutan seri Johansen, dan FAA.

Alat yang digunakan pada penelitian adalah timbangan digital (Durascale), corong plastik, kain blacu, nilon 150 mesh, beaker glass, gelas ukur, magnetic stirrer, mikrotom, cover glass, dan mikroskop cahaya (Olympus BH-2), hot plate stirrer MAG-Mixer type MH-61, termometer, timer, plat kaca, oven (Memmert), Whiteness Meter model C-100, tensile strength and elongation tester (StographMi Toyoseiki), moisture cup Moisture Pervios Cups (Toyoseiki), dan Digital Thickness (Adamel Lhomargy).

\section{Metode Penelitian}

Penelitian ini terdiri beberapa tahap meliputi analisis proksimat buah lindur (AOAC 2005), pembuatan tepung pati dari buah lindur (Modifikasi Rini 2004), pengujian karakteristik tepung pati buah lindur yang dihasilkan (kadar air, pati, amilosa, amilopektin, derajat putih) (AOAC, 1995), pembuatan edible film (Modifikasi Fransiska 2008) dan pengujian karakteristik edible film yang dihasilkan (ketebalan, kuat tarik, persen pemanjangan edible film, dan laju trasmisi uap air edible film) (ASTM 1989).

\section{Pembuatan Tepung Pati Buah Lindur (Modifikasi Rini 2004)}

Proses ini dimulai dengan pengupasan, pembersihan, pemotongan dan penghalusan buah lindur yang sebelumnya ditambah natrium metabisulfit sebanyak $0,05 \%(\mathrm{~b} / \mathrm{v})$ dan air 1:2 (b/v). Bubur buah lindur disaring dengan kain blacu. Ampas yang dihasilkan ditambah dengan air 1:1 dan dilakukan pengulangan sebanyak dua kali. Larutan pati diendapkan pada suhu $4^{\circ} \mathrm{C}$ selama 6 jam. Air hasil pengendapan dibuang. Pati dicuci dengan menambahkan air sebanyak 1:1 dan diendapkan pada suhu $4^{\circ} \mathrm{C}$ selama 6 jam. Pengendapan pati berikutnya dilakukan selama 12 jam. Pati dikeringkan pada suhu $50^{\circ} \mathrm{C}$ selama 8-12 jam. Serpihan pati kemudian dihaluskan dan diayak dengan saringan 100 mesh.

\section{Pembuatan Edible Film (Modifikasi Fransiska 2008).}

Pati dilarutkan dalam akuades dengan konsentrasi $4 \%$ dengan magnetic stirrer dan dipanaskan di atas hot plate stirrer pada suhu (60$70)^{\circ} \mathrm{C}$ selama 20 menit. Karagenan konsentrasi $2 \%$; $2,5 \%$ dan $3 \%$ dilarutkan dalam akuades, diaduk dengan magnetic stirrer dan dipanaskan di atas hot plate hingga suhu mencapai $80^{\circ} \mathrm{C}$. Larutan karagenan kemudian dicampurkan dengan larutan pati pada suhu $(70-80)^{\circ} \mathrm{C}$, hingga homogen. Gliserol 1\% dan 1,5\% dimasukkan ke dalam larutan tersebut. Larutan edible film kemudian dituang pada plat kaca sesuai ukuran. Film pada plat kaca dikeringkan dalam oven pada suhu $60^{\circ} \mathrm{C}$ selama 5-6 jam. 


\section{HASIL DAN PEMBAHASAN}

\section{Morfologi Tumbuhan Lindur}

Tumbuhan lindur memiliki daun yang umumnya berwarna hijau tua dan berbentuk elips. Daunnya dikenal dengan large-leafed mangrove karena memiliki panjang antara $(8-22) \mathrm{cm}$ dan lebar antara $(5-8) \mathrm{cm}$. Ujung daun meruncing, berwarna hijau pada bagian atas dan hijau kekuningan pada bagian bawah dengan bercak-bercak hitam. Batang dari tumbuhan ini umumnya berwarna abuabu sampai hitam, memiliki lentisel yang besar dengan percabangan simpodial. Akar membentukakar papan dan melebar kesamping tetapi juga memiliki sejumlah akar lutut.

Tumbuhan lindur juga memiliki bunga dan buah, bunga terletak di ujung buah dengan kelopak berwarna merah muda hingga merah serta panjang bunga berkisar antara (1,5$3,5) \mathrm{cm}$. Buah berbentuk silinder (hipokotil), melingkar spiral dengan lebar $(2-2,5) \mathrm{cm}$ dan panjang antara $12-30 \mathrm{~cm}$ (James dan Duke 2006).

\section{Komposisi Kimia Buah Lindur Segar}

Kadar proksimat buah lindur segar adalah kadar air 62,92\%; kadar abu 1,29\%; kadar lemak 0,79\%; kadar protein 2,11\%; dan kadar karbohidrat 32,91\% (Tabel 1). Penelitian yang dilakukan oleh Fortuna (2005) menunjukkan komposisi kadar air buah lindur sebesar $73,76 \%$; kadar abu yang sebesar $0,34 \%$; kadar lemak sebesar 1,25\%; kadar protein sebesar 1,13\%; dan kadar karbohidrat sebesar 23,53\%. Variasi komposisi kimia ini disebabkan oleh faktor spesies, umur, lamanya penyinaran matahari, asupan nutrisi yang tersedia, dan habitat tempat hidupnya.

\section{Karakteristik Tepung Pati Buah Lindur}

Kandungan air tepung pati buah lindur yang dihasilkan dibawah $14 \%$ yaitu $6,19 \%$ (Tabel 2) yang menjadikan tepung pati buah lindur dapat disimpan hingga jangka yang lama. Semakin tinggi kadar air tepung pati buah lindur maka akan menimbulkan gelembung yang semakin banyak pada larutan edible film. Gelembung-gelembung ini akan menjadikan edible film yang dihasilkan memiliki penampakan yang kurang baik setelah dikeringkan. Tepung yang baik hendaknya memiliki kadar air yang tidak lebih dari 14\%, karena batas toleransi mikroba masih dapat tumbuh pada 14-15\% (Richana dan Titi 2004).

Kandungan amilosa dan amilopektin akan menentukan karakteristik film yang dihasilkan. Rasio amilosa dan amilopektin tergantung dari jenis pati. Semakin tinggi kandungan amilosa maka film akan semakin kuat (Schultz 1969). Kandungan amilosa dan amilopektin buah lindur hasil penelitian diperoleh sebesar $31,56 \%$ dan $26,17 \%$ (Tabel 2).

Tabel 1 Komposisi kimia buah lindur segar dan tepung pati buah lindur

\begin{tabular}{lcc}
\hline \multicolumn{1}{c}{ Komposisi } & Jumlah $(\%)^{\mathrm{a}}$ & ${\text { Jumlah }(\%)^{\mathrm{b}}}^{\text {Kadar air }}$ \\
Kadar abu & 62,92 & 6,19 \\
Kadar lemak & 0,29 & - \\
Kadar protein & 2,11 & - \\
Karbohidrat & 32,91 & - \\
Pati & - & - \\
Amilosa & - & 57,73 \\
Amilopektin & - & 31,56 \\
Lain-lain & - & 26,17 \\
\hline
\end{tabular}

Keterangan: abuah lindur segar; ${ }^{b}$ tepung pati buah lindur 
Tabel 2 Karakteristik fisik tepung pati buah lindur

\begin{tabular}{lc}
\hline \multicolumn{1}{c}{ Parameter } & Stasiun \\
\hline Derajat Putih & $37,37 \%$ \\
Bentuk Granula & $\begin{array}{c}\text { lonjong melebar } \\
\text { panjang } 11,21 \mu \mathrm{m} ; \\
\text { lebar } 28,9 \mu \mathrm{m}\end{array}$ \\
Ukuran Granula & putih kecoklatan \\
\hline
\end{tabular}

Pati terbentuk dari proses asimilasi dalam tumbuhan yang disebut fotosintesis. Pati terbentuk pada siang hari ketika proses fotosintesis melebihi laju gabungan antara respirasi dan translokasi. Rantai-rantai amilosa dan amilopektin dalam butiran pati tersusun dalam bentuk semi kristal, yang menyebabkannya tidak larut dalam air dan memperlambat pencernaannya oleh amilase pankreas (Shiihii et al. 2011). Struktur kristal pati akan rusak dan rantai polisakarida akan mengambil posisi acak, bila pati dipanaskan dengan air. Kondisi ini yang menyebabkan pati mengalami pengembangan dan pemadatan (gelatinisasi). Proses pemanasan pati disamping menyebabkan pembentukan gel juga akan melunakkan dan memecah sel pati sehingga memudahkan pencernaanya di dalam tubuh terutama bagian lambung apabila pati dikonsumsi (Richard et al. 2004).

Derajat putih merupakan tingkat warna putih dari pati dibandingkan dengan warna putih $\mathrm{BaSO}_{4}$ (100\%). Derajat putih tepung pati buah lindur berdasarkan hasil penelitian mempunyaiderajatputihsebesar $37,37 \%$ (Tabel 3), hal ini disebabkan oleh senyawa polifenol yang menyebabkan adanya rekasi pencoklatan pada tepung pati buah lindur. Bentuk granula pati buah lindur adalah lonjong dan melebar pada bagian atas, dengan panjang dan lebar granula antara 11,21 $\mu \mathrm{m}-28,9 \mu \mathrm{m}$ (Tabel 3). Granula pati umumnya banyak ditemukan pada berbagai jaringan tanaman, mempunyai bentuk, ukuran, keseragaman dan bentuk hilum (sentrik dan eksentrik) yang khas untuk setiap jenis pati, sehingga dapat digunakan untuk identifikasi jenis pati (Swinkles 1985). Granula pati mempunyai sifat birefringence, yaitu sifat yang dapat merefleksikan cahaya terpolarisasi membentuk bidang berwarna jingga dan biru. Warna biru pada granula pati menunjukkan kandungan amilosa dan warna jingga menunjukkan adanya kandungan amilopektin.

Buah lindur yang telah dikupas cenderung mengalami perubahan warna akibat adanya reaksi pencoklatan secara enzimatik. Reaksi enzimatik terjadi karena oksidasi yang dikatalis oleh enzim fenolase (Garcia et al. 2009). Warna tepung pati buah lindur yang dihasilkan adalah putih kecoklatan. Warna ini dipengaruhi oleh reaksi enzimatik yang dialami oleh buah lindur dan dipengaruhi oleh penambahan natrium metabisulfit pada proses pembuatan pati. Penambahan natrium metabisulfit bertujuan untuk mempertahankan derajat putih tepung pati buah lindur. Penambahan natrium metabisulfit dapat mencegah timbulnya warna coklat akibat reaksi anzimatik yaitu dengan adanya reaksi antara natrium metabisulfit dengan enzim.

\section{Karakteristik Edible Film}

Nilai ketebalan yang dihasilkan dari keenam edible film yang dihasilkan relatif berbeda, walaupun luas cetakan, volume larutan dan total padatan dalam larutan tidak berbeda antara masing-masing formula (Tabel 4). Ketebalan merupakan parameter yang sangat penting karena akan berpengaruh terhadap tujuan penggunaanya untuk pengemas atau pelapis produk. Perbedaan nilai ketebalan disebabkan oleh sifat gliserol, karagenan dan pati yang sama-sama bersifat hidrofilik sehingga mengikat lebih banyak air yang akan menguap setelah proses pengovenan (Trilaksani et al. 2007).

Ketebalan akan mempengaruhi laju transmisi uap air dan gas sehingga mempengaruhi produk yang dikemas. Semakin tinggi nilai ketebalannya maka sifat dari edible film yang dihasilkan akan semakin kaku dan keras serta dengan produk yang dikemas akan semakin aman dari pengaruh 
Tabel 3 Hasil karakteristik edible film

\begin{tabular}{clcccc}
\hline Kode & \multicolumn{1}{c}{ Keterangan } & $\begin{array}{c}\text { Ketebalan } \\
(\mathrm{mm})\end{array}$ & $\begin{array}{c}\text { Kuat tarik } \\
\left(\mathrm{kgf} / \mathrm{cm}^{2}\right)\end{array}$ & $\%$ Pemanjangan & $\begin{array}{c}\text { WVTR } \\
\mathrm{g} / \mathrm{m}^{2} / 24 \text { jam }\end{array}$ \\
\hline A & P 4\%, G 1\%, K 2\%, & 0,20 & 159,48 & 52,25 & 231,23 \\
B & P 4\%, G 1\%, K 2,5\% & 0,16 & 164,76 & 57,42 & 273,20 \\
C & P 4\%, G 1\%, K 3\% & 0,17 & 165,53 & 17,77 & 246,06 \\
D & P 4\%, G 1,5\%, K 2\% & 0,13 & 132,88 & 126,54 & 259,59 \\
E & P 4\%, G 1,5\%, K 2,5\% & 0,14 & 168,33 & 181,21 & 256,00 \\
F & $4 \%$, G 1,5\%, K 3\% & 0,14 & 167,74 & 66,92 & 298,82 \\
\hline
\end{tabular}

luar. Park et al. (1996) menyatakan bahwa ketebalan edible film dipengaruhi oleh luas cetakan, volume larutan, dan banyaknya total padatan dalam larutan.

Penurunan nilai ketebalan dengan penambahan gliserol dan penambahan konsentrasi karaginan yang lebih tinggi dikarenakan gliserol 1\% dan karagenan mampu membentuk ikatan molekul sehingga pada saat pemanasan air yang hilang tidak terlalu banyak dibandingkan dengan formula penambahan gliserol sebesar $1,5 \%$ yang kehilangan air lebih banyak sehingga menghasilkan ketebalan film yang kecil. Gliserol menurut Gontard et al. (1993) merupakan senyawa alkohol polihidrat dengan tiga gugus molekul hidroksil sehingga mudah berikatan dengan air dan bila mengalami pemanasan air yang terikat mudah menguap. Baldwin et al. (1995) menyatakan bahwa lembaran film terbentuk pada saat proses pengovenan berlangsung. Larutan film akan mengalami penguapan air sehingga akan terjadi pengkerutan partikel yang akan akan membentuk lembaran film. Proses pembentukan film diawali dengan memudarnya jarak antar pertikel yang saling berikatan dalam suatu cairan sehingga setelah terjadi proses penguapan akan terbentuk suatu lembaran film.

\section{Kuat Tarik}

Nilai kuat tarik formula A, C, D lebih kecil dibandingkan dengan nilai kuat tarik formula D, E, F (Tabel 4). Kuat tarik adalah regangan maksimal yang masih dapat diterima oleh sampel film sebelum putus (McHugh dan Krochta 1994). Penambahan konsentrasi karagenan akan meningkatkan nilai kuat tarik edible film, karena karaginan mampu membentuk matriks polimer yang kuat dan menjadikan kekuatan tarik intermolekul semakin kuat pada edible film (Krochta dan Johnston 1997), hal ini dapat dilihat dari peningkatan nilai kuat tarik antara formula B dan $\mathrm{E}$, begitu pula antara formula $\mathrm{C}$ dengan F. Peningkatan konsentrasi karaginan akan mempengaruhi padatan terlarut dalam edible film. Gliserol dan karagenan akan larut dalam tiap-tiap rantai polimer dan mengisi semua ruang sehingga mengurangi gerakan molekul polimer dan akan menaikkan suhu transisi gelas. Semakin meningkatnya suhu transisi gelas maka polimer yang terbentuk akan semakin keras dan kuat tarik yang terbentuk akan semakin tinggi (Garcia et al. 2000).

Penambahan gliserol pada ediblefilm dapat mengakibatkan penurunan gaya intermolekul yang akan menyebabkan menurunnya kekuatan tarik yang terlihat antara formula A dan D. Penambahan gliserol yang akan larut dalam tiap-tiap rantai polimer sehingga akan mempermudah gerakan molekul polimer dan bekerja menurunkan suhu transisi gelas. Polimer yang terbentuk akan semakin lunak jika suhu transisi gelas diturunkan hal ini akan menyebabkan kuat tariknya semakin makin rendah (Park et al. 1996).

\section{Persen Elongasi}

Hasil pengujian persen elongasi edible 
film disajikan pada Tabel 4, yang menunjukkan semakin besar penambahan plasticizer maka persen pemanjanganpun akan semakin bertambah, tetapi setelah penambahan pada konsentrasi tertentu nilainya akan menurun. Persen pemanjangan adalah keadaan saat film patah setelah mengalami perubahan ukuran panjang dari ukuran yang sebenarnya pada saat mengalami peregangan. Sifat ini sangat penting dan mengindikasikan kemampuan film dalam menahan beban sebelum film itu putus. Gliserol dalam fungsinya sebagai plasticizer menurunkan ikatan kohesi mekanik antara polimer dan dapat merubah sifat rigiditasnya sehingga film yang terbentuk lebih fleksibel. Gliserol memiliki bobot molekul yang kecil sehingga dapat bergabung dalam matriks film dan meningkatkan fleksibilitas serta kemampuan membentuk film (Banker 1996).

Semakin banyak konsentrasi plasticizer maka ikatan kohesi antar polimer akan semakin kecil dan film yang terbentuk akan lebih lunak sehingga edible film yang terbentuk mudah putus (Bourtoom 2008). Penambahan karaginan pada konsentrasi $3 \%$ akan menurunkan persen pemanjangan edible film yang dihasilkan yang dapat dilihat pada formula $\mathrm{C}$ dan $\mathrm{F}$, hal ini dikarenakan semakin banyak konsentrasi karaginan yang ditambahkan maka padatan terlarut dalam film semakin meningkat. Semakin bertambah konsentrasi karaginan yang larut dalam tiap-tiap rantai polimer edible film maka semua ruang akan terisi sehingga mengurangi gerakan molekul polimer yang akan menaikkan suhu transisi gelas. Polimer yang terbentuk akan semakin kaku jika suhu transisi gelas meningkat, hal ini akan menyebabkan film tidak fleksible sehingga mudah patah saat mengalami peregangan (McHugh dan Krochta 1994).

\section{Laju Transmisi Uap Air}

Laju Transmisi Uap Air (Water Vapour Transmition Rate/WFTR) merupakan laju transmisi uap air melalui suatu unit luasan bahan yang permukaannya rata dengan ketebalan tertentu, sebagai akibat dari suatu perbedaan unit tekanan uap antara dua permukaan tertentu pada kondisi dan suhu tertentu (Krochta et al. 1997). Nilai laju transmisi uap air dari keenam formula edible film yang dihasilkan disajikan pada Tabel 4 . Permeabilitas menyangkut proses pemindahan larutan dan difusi saat larutan berpindah dari satu sisi film dan selanjutnya berdifusi ke sisi film yang lainnya. Semakin tebal edible film yang dihasilkan maka kemampuan edible film dalam menahan uap air akan semakin baik. Gliserol memiliki gugus hidrofilik yang akan mengurangi kerapatan molekul sehingga terbentuk ruang bebas pada matriks film yang memudahkan difusi uap air (Ruan et al. 1998). Karagenan marupakan salah satu bahan dalam pembuatan edible film yang tergolong hidrokoloid dan umumnya merupakan bahan yang buruk daya tahannya terhadap uap air. Sifat karaginan yang hidrofilik menyebabkan edible film yang dihasilkan dapat dengan mudah menyerap uap air (Bourtoom 2008). Edible film berbasis pati merupakan penghalang yang baik terhadap $\mathrm{O}_{2}$ dan $\mathrm{CO}_{2}$ serta merupakan film yang dapat larut di dalam air (Leloup et al. 1991). McHugh dan Krochta (1994) menyatakan bahwa permeabilitas dipengaruhi oleh sifat kimia bahan, struktur polimer, kondisi uji dan sifat dari bahan yang akan berdifusi.

\section{KESIMPULAN}

Sesuai dengan pengembangan enam formula edible film yang diujikan diperoleh nilai ketebalan edible film yang dihasilkan berkisar 0,13-0,20 $\mathrm{mm}$, nilai kuat tarik $132,88-168,33 \mathrm{kgf} / \mathrm{cm}^{2}$, nilai persen pemanjangan $181,21-17,77 \%$ dan nilai laju transmisi uap air 231,23-298,82 g/m²/24 jam.

\section{DAFTAR PUSTAKA}

[AOAC] Association of Analytical Chemist Publiser. 1995. Official Methods of Analysis. 16th edition. New York: Arlington, Inc.

[AOAC] Association of Official Analytical 
and Chemist. 2007. Official Methods of Analysis. 18thedition. Marylan: Association of Official Analytical Chemist Inc

[ASTM] American Society for Testing and Material. 1989. Standard Method For Oxygen Gas Transmission Rate of Material. Philadelphia: ASTM Book of Standards D3985-81.

Anggraini 2012. Karakteristik edible film dari pati sagu dengan penambahan gliserol dan karaginan. Jurnal Pangan dan Agroindustri 1:12-16.

Astuti T, Sri D. 2010. Perkembangan serat batang rosella (Hibiscus sabdariffa) dengan perlakuan naungan dan volume penyiraman yang berbeda. Buletin Anatomi dan Fisiologi 18(2): 47-55.

Banker GS. 1996. Film coating theory and practice. Journal Pharmacy Science 55(1): 81-89.

Baldwin EA, Nisperos-Carriedo MO, Baker RA. 1995. Edible coating for lightly processed friuts and vegetables. Journal Horticultural Science 30(1):35-38.

Bourtoom T. 2008. Review article edible films and coatings: characteristics and properties. Journal International Food Research 15(3):237-248.

Fennema O, Donhowe IG, Kester JJ. 1994. Lipid type and location of the relative humidity gradient influence on the barrier properties of lipid to water vapor. Journal of Food Engineering 22(1):225-239.

Fortuna JD. 2005. Ditemukan Buah Bakau sebagai Makanan Pokok. http//www. ebookpangan.com. 2006 [10 Oktober 2011].

Fransiska D. 2008. Aplikasi karaginan untuk pembuatan pengemas lapis tipis biodegradable dengan komposit wheat gluten dan lilin lebah (beewax). Prosiding Seminar Nasional Tahunan $V$ Hasil Penelitian Perikanan dan Kelautan. 26 Juni 2008.Yogyakarta: Universitas Gadjah Mada

Garcia MA, Martino MN, Zaritzky NE.
2000. Lipid addition to improve barrier properties of edible starch-based films and coatings. Journal of Food Science 65(2):941-947.

García PG, SeGoVIa B, LóPez L, Jaren GM, GarrIdo F. 2009. Mechanism and polyphenols involved in the browning reaction of olives. Journal of Food Science 27(2):195-206.

Gontard N, Guilbert S, Cuq JL. 1993. Water and glycerol as plasticizer affect mechanical and water vapor barrier properties of edible wheat gluten film. Journal of Food Science 58: 1346-1370.

Handito D. 2011. Karakteristik edible film dari karaginan. Jurnal Teknologi Pangan 9: 1520.

James AA, Duke NC. 2006. Bruguiera gymnorrhiza (large-leafed mangrove). Species Profiles for Pacific Island Agroforestry 2(1):1-15.

Kusumawaty DH, Putri WDR. 2013. Karakteristik fisik dan kimia edible film jagung yang diinkorporasi dengan perasan temu hitam. Jurnal Pangan dan Agroindustri 1(1): 90-100.

Krochta JM, Johnston CDM. 1997. Edible and biodegradable polymer film. Journal of Food Technology 52(2): 1-20.

Leloup LM, Colonna P, Buleon A. 1991. Influence of amylase-amylopektin on gel properties. Journal Cereal Science 13(2): 1-13.

McHugh TH, Krochta JM. 1994. Sorbitol vs gliserol plasticized whey protein edible films: integrated oxygen permeability and tensile strength property evaluation. Journal of Agricultural and Food Chemistry 42(4):841-845.

Park JW, Testin RF, Vergano DJ, Park KJ, Weller CL, 1996. Application of laminated edible film to potato chip packaging. Journal of Food Science 61(4): 66-76.

Richana N, Titi CS. 2004. Karakterisasi sifat fisikokimia tepung umbi dan tepung pati umbi ganyong, suweg,ubi kelapa dan gembili. Jurnal Pascapanen 1(1):29-37. 
Richard FT, John K, Xin Q. 2004. Starch composition, fine structure and architecture. Journal of Cereal Science 39(2):151-165.

Rini HA. 2004. Karaktersitik sifat fisiko-kimia dan fungsional tepung dan pati bonggol pisang [Tesis]. Bogor: Program Pasca Sarjana, Institut Pertanian Bogor.

Ruan RR, Xu L, Chen PL. 1998. Water vapour permeability and tensile strength of cellulose-based composite edible film. Applied Engineering in Agriculture 14(4): 411-413.

Schultz HW. 1969. Symposium on foods: carbohydrates and their roles. Journal
Food Science American 11(46):449-458.

Swinkles JJM. 1985. Composition and properties of commercial native starches. Journal of Starch/Stark 37: 1 - 5.

Shiihii SU, Musa H, Bhatia PG, Martins E. 2011. Evaluation of physicochemical properties of Eleusine coracana starch. Journal of Pharmaceutical Sciences 10(1): 91-102.

Trilaksani W, Bambang R, Siti NKA. 2007. Karakteristik edible film dari konsentrat protein air limbah surimi ikan nila (Oreochromis niloticus). Buletin Teknologi Hasil Perikanan 10(2):60-72. 